\title{
BIOAKTIVITAS BIJI KOLOWE (CHYDENANTHUS EXCELSUS) TERHADAP LARVA NYAMUK AEDES AEGYPTY
}

\author{
Laode Rijai \\ Kelompok Bidang Ilmu Kimia Farmasi, Fakultas Farmasi Universitas Mulawarman \\ Samarinda \\ e-mail:najwankhanrjai@yahoo.co.id
}

\begin{abstract}
ABCTRACT
Kolowe seed (Chydenanthus excelsus) bioactivity against Aedes aegypti masquito larvae was investegated. Assay of Kolowe seed preparation used fresh seed powder, dry powder, rough extract (methanol extract), $n$ - butanol extract fraction, and aethyl acetate extract fraction. Plant material taken from Kamaru, Buton, Indonesia on March 2007. Fresh powder bioactivity $(L C 50=230.60 \mathrm{ppm})$; dry powder $(L C 50=225.55 \mathrm{ppm})$; rough extract/ methanol $(L C 50=245.70 \mathrm{ppm}) ; n$ - butanol extract fraction $(L C 50=235.75 \mathrm{ppm}) ;$ aethyl acetate extract fraction $(L C 50=250.55 \mathrm{ppm})$. The research results illustrated that the bioactivity seed from kolowe strong enough against mosquito larvae A. aegypti and dry powder has a stronger bioactivity than the other.
\end{abstract}

Keywords : Kolowe Seed (Chydenanthus excelsus), Aedes aegypti mosquito larvae

\begin{abstract}
ABSTRAK
Penelitian bioaktivitas biji kolowe (Chydenanthus excelsus) terhadap larva nyamuk Aedes aegypti telah dilakukan. Sediaan biji kolowe yang diuji adalah serbuk biji segar, serbuk kering, ekstrak kasar (ekstrak metanol), ekstrak fraksi $n$-butanol, dan ekstrak fraksi etilasestat. Bahan tumbuhan diambil dari Kamaru, Buton, Indonesia pada bulan Maret 2007. Bioaktivitas serbuk segar $($ LC50 $=230,60 \mathrm{ppm})$; serbuk kering $($ LC50 $=225,55 \mathrm{ppm})$; ekstrak kasar/metanol $(\mathrm{LC} 50=245,70 \mathrm{ppm})$; ekstrak fraksi n-butanol $(\mathrm{LC} 50=235,75 \mathrm{ppm})$; ekstrak fraksi etilasetat $($ LC50 $=250,55 \mathrm{ppm})$. Hasil penelitian tersebut menggambarkan bahwa bioaktivitas biji kolowe cukup kuat terhadap larva nyamuk $A$. aegypti dan serbuk kering memiliki bioaktivitas lebih kuat dari lainnya.
\end{abstract}

Kata Kunci: Biji Kolowe (Chydenanthus excelsus), larva nyamuk Aedes aegypti

\section{PENDAHULUAN}

Tumbuhan kolowe adalah spesies langka yang hanya ditemukan di kepulauan Andaman, Myanmar dan kepulauan Buton, Indonesia) ${ }^{\mathbf{1}}$. Tumbuhan ini berbuah secara terus menerus atau tidak bermusim. Buah dan daunnya digunakan oleh masyarakat
Kamaru, Buton sebagai racun ikan, bahkan menjadi bahan untuk menangkap ikan laut pada areal laut pasang surut kering (surut hingga kering). Belum ada kasus pencemaran akibat penggunaan buah tersebut pada areal perairan. Secara kimia sifat racun ikan dapat disebabkan oleh metabolit sekunder kelompok saponin, 
selain kelompok senyawa lainnya. Saponin memiliki multi potensi seperti racun ikan (fisisidal), sitotoksik, bakterisida, insektisida, antifeedant, fungisida, dan berbagai obat-obatan lainnya) ${ }^{2}$. Dari aspek ilmiah, penelitian saponin berpeluang menemukan senyawa baru karena kelompok senyawa ini sangat bervariasi jenisnya dan sukar dipisahkan dengan teknik-teknik pemisahan konvensional. Selain itu keberadaan saponin dalam suatu spesies dapat menggambarkan biogenesis spesies tersebut karena saponin adalah bentukan dari triterpen/steroid dengan molekul gula. Dengan demikian penelitian saponin dari suatu spesies memberikan manfaat aplikasi dalam pemanfaatan spesies sebagai sumber bioaktif dan manfaat ilmiah dalam aspek temuan baru senyawa dan biogenesis spesies. Biji kolowe mengandung saponin sebagai konstituen utama hingga 46,2 \% pada fraksi $n$-butnaol) ${ }^{3}$. Pada skrining awal telah terbukti aktif terhadap larva udang Artemia salina. Bukti tersebut dapat menggambarkan potensi pestisida, termasuk insektisida) ${ }^{4}$. Penelitian ini melakukan pengujian bioaktivitas biji kolowe terhadap larva nyamuk $A$. aegypti. Makna dari penelitian ini adalah memanfaatkan biji kolowe pada aspek lain termasuk pembasmi jentik nyamuk vektor Deman Berdarah Dungue (DBD).

\section{METODE PENELITIAN}

Bahan tumbuhan diambil dari Kamaru, Buton, Indonesia, karena tumbuhan tersebut di Indonesia baru ditemukan di daerah tersebut. Sebanyak 38 buah kolowe segar dikupas dan diperoleh biji segar 1480 g. Biji kolowe tersebut diarajang lalu dikeringkan dengan cara menjemur pada sinar matahari langsung dengan menghindarkan hujan. Penetapan bahwa biji kolowe telah kering dilakukan dengan pengamatan secara visual fisik bahan dan pengukuran kadar air hingga toleransi 5\%. Biji kolowe yang telah dinyatakan kering, digiling dengan blender hingga diperoleh serbuk kering. Serbuk kering yang diperoleh dari pengerjaan tersebut adalah 950 g. Untuk mendapatkan jumlah serbuk yang lebih banyak, dilakukan ulangan dengan cara yang sama.

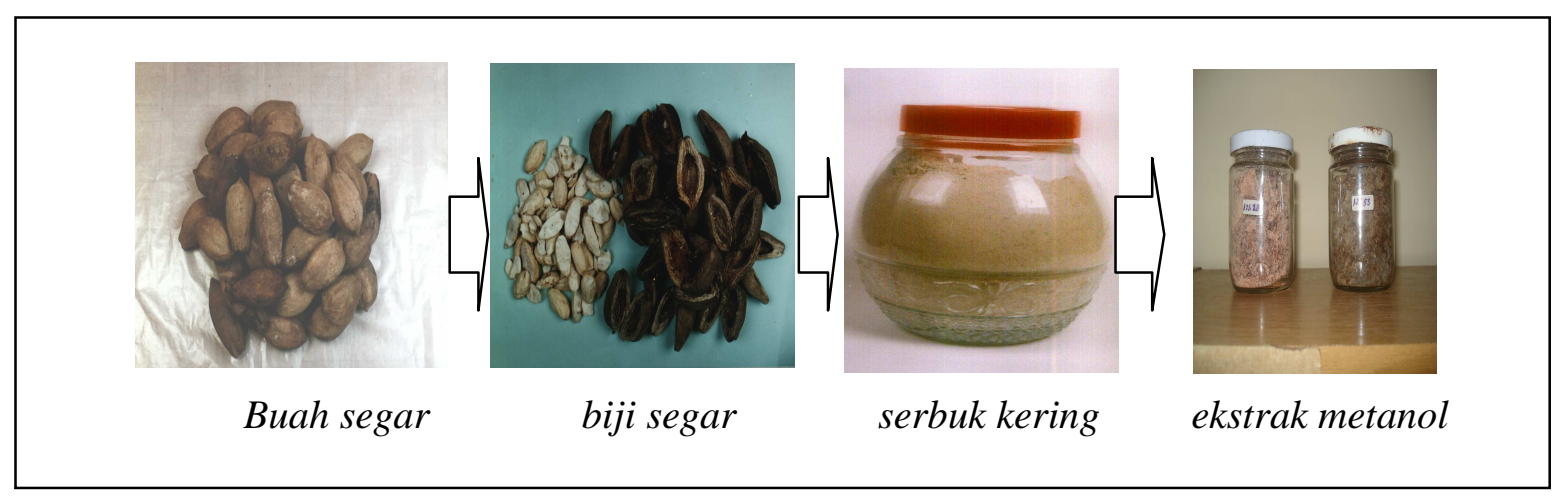

Gambar 1. Contoh buah kolowe (C. excelsus) 
Selanjutnya, $800 \mathrm{~g}$ serbuk kering tersebut dimaserasi dengan metanol 5 x 24 jam @ 2 L. Ekstrak yang diperoleh setelah pelarutnya diuapkan adalah $245 \mathrm{~g}$. Sebanyak $100 \mathrm{~g}$ ekstrak kental tersebut difraksinasi secara gradien yaitu dengan etilasetat:air dan n-butanol :air.

Ekstrak hasil fraksinasi yang diperoleh masing-masing etilasasetat dan n-butanol adalah 12,5 g dan 31,8 g. Dengan demikian jumlah sampel yang siap untuk perlakuan berikutnya pada pengerjaan pertama adalah: serbuk kering $150 \mathrm{~g}(950 \mathrm{~g}$ - $800 \mathrm{~g}), 145 \mathrm{~g}$ ekstrak metanol (245 g $100 \mathrm{~g}), 12,5 \mathrm{~g}$ ekstrak fraksi etilasetat, dan $31,8 \mathrm{~g}$ ekstrak fraksi n-butanol. Untuk mendapatkan ekstrak yang lebih banyak, dilakukan pengerjaan ulangan dengan prosedur tersebut.

Selanjutnya, dilakukan penetapan seri kosentrasi batas bawa dan batas atas untuk eksperimen dilakukan dengan cara menguji beberapa nilai kosentrasi. Nilai seri kosentrasi batas bawa yang digunakan adalah nilai kosentrasi terendah dimana pada kosentrasi tersebut telah menunjukkan adanya larva yang mati atau tidak menjadi pupa nyamuk; sedangkan nilai kosentrasi batas atas adalah pada nilai kosentrasi tertinggi tetapi masih ada hewan uji yang hidup. Berdasarkan hasil tersebut, maka seri kosentrasi percobaan yang digunakan ditunjukkan pada Tabel 1. Selanjutnya dilakukan penyiapan larva nyamuk $A$. aegypty sebagai bioindikator pengujian. Telur nyamuk diperoleh dari Laboratorium Insektarium, Puslitbang Ekologi Kesehatan, Badan Litbang Kesehatan, Jakarta. Telur nyamuk $A$. aegypti dicelupkan dalam air suling pada wadah dengan permukaan lebar, telur menetas setelah 24 jam menjadi larva instar I.
Larva dipelihara dengan pemberian pakan berupa pelet yang telah dihaluskan dan jentik menjadi instar III (selama 3-4 hari). Perubahan setiap instar ditunjukkan dengan terjadinya ecdysis (pengelupasan kulit). Instar III tersebut merupakan larva dan siap untuk diuji.

Pengujian bioaktivitas terhadap larva nyamuk $A$. aegypty tersebut dilakukan pada tabung vial. Tabung vial yang telah berisi larutan sampel uji (sampel dalam air suling) sesuai dengan seri kosentrasi Tabel 1 dimasukan 20 ekor larva nyamuk $A$. aegypti setiap tabung. Pengamatan dilakukan 24 jam kemudian dengan menghitung jumlah larva yang hidup dan mati. Untuk larutan ekstrak fraksi etilasetat ditambahkan DMSO sekitar $80 \mu \mathrm{L}$ karena sukar larut dalam air. Rancangan pengujian bioaktivitas biji kolowe terhadap larva nyamuk $A$. aegypty ditunjukkan pada Tabel 2 dan 3.

Rancangan penelitian menggunakan Rancangan Acak Lengkap (RAL) yang terdiri dari dua faktor yaitu faktor perlakuan dan faktor pengamatan.

\section{HASIL DAN PEMBAHASAN}

Hasil pengujian bioaktivitas biji kolowe ( $C$. excelsus) terhadap larva nyamuk $A$. aegypty ditunjukkan pada Tabel 4.Pengujian dilakukan terhadap telur nyamuk Aedes aegypti dengan mengamati jumlah larva yang tumbuh menjadi pupa dan yang tidak menjadi pupa.

Larva yang tidak menjadi pupa pada pertumbuhan diindikasikan sebagai pengaruh ekstrak biji kolowe yang telah diberikan. 
Tabel 1. Seri kosentrasi Uji bioaktivitas terhadap larva nyamuk A. aegypti

\begin{tabular}{crrrrr}
\hline \multirow{2}{*}{ Ulangan } & \multicolumn{5}{c}{ Kosentrasi dalam ppm } \\
\cline { 2 - 6 } & 100 & 200 & 300 & 400 & Kontrol \\
\hline I & & & & & \\
II & & & & & \\
III & Rata-rata & Rata-rata & Rata-rata & Rata-rata & \\
& & & & & \\
\end{tabular}

Tabel 2. Rancangan pengujian bioaktivitas biji Kolowe (C. excelsus) Serbuk Segar, Serbuk Kering dan Ekstrak Kasar Metanol terhadap larva nyamuk A. aegypti

\begin{tabular}{ccccccccc}
\hline \multicolumn{3}{c}{ Serbuk Segar (SS) } & \multicolumn{3}{c}{ Serbuk Kering (SK) } & \multicolumn{3}{c}{ Ekstrak Metanol (EM) } \\
\hline $\mathrm{SSK}_{1} \mathrm{U}_{1}$ & $\mathrm{SSK}_{2} \mathrm{U}_{1}$ & $\mathrm{SSK}_{3} \mathrm{U}_{1}$ & $\mathrm{SKK}_{1} \mathrm{U}_{1}$ & $\mathrm{SKK}_{2} \mathrm{U}_{1}$ & $\mathrm{SKK}_{3} \mathrm{U}_{1}$ & $\mathrm{EMK}_{1} \mathrm{U}_{1}$ & $\mathrm{EMK}_{2} \mathrm{U}_{1}$ & $\mathrm{EMK}_{3} \mathrm{U}_{1}$ \\
$\mathrm{SSK}_{1} \mathrm{U}_{2}$ & $\mathrm{SSK}_{2} \mathrm{U}_{2}$ & $\mathrm{SSK}_{3} \mathrm{U}_{2}$ & $\mathrm{SKK}_{1} \mathrm{U}_{2}$ & $\mathrm{SKK}_{2} \mathrm{U}_{2}$ & $\mathrm{SKK}_{3} \mathrm{U}_{2}$ & $\mathrm{EMK}_{1} \mathrm{U}_{2}$ & $\mathrm{EMK}_{2} \mathrm{U}_{2}$ & $\mathrm{EMK}_{3} \mathrm{U}_{2}$ \\
$\mathrm{SSK}_{1} \mathrm{U}_{3}$ & $\mathrm{SSK}_{2} \mathrm{U}_{3}$ & $\mathrm{SSK}_{3} \mathrm{U}_{3}$ & $\mathrm{SKK}_{1} \mathrm{U}_{3}$ & $\mathrm{SKK}_{2} \mathrm{U}_{3}$ & $\mathrm{SKK}_{3} \mathrm{U}_{3}$ & $\mathrm{EMK}_{1} \mathrm{U}_{3}$ & $\mathrm{EMK}_{2} \mathrm{U}_{3}$ & $\mathrm{EMK}_{3} \mathrm{U}_{3}$ \\
\hline
\end{tabular}

Tabel 3. Rancangan pengujian bioaktivitas biji Kolowe (C. excelsus) Ekstrak fraksi Etilasetat dan Ekstrak fraksi n-Butanol terhadap larva nyamuk A. aegypti

\begin{tabular}{cccccc}
\hline \multicolumn{2}{c}{ Ekstrak Fraksi Etilasetat (EA) } & \multicolumn{3}{c}{ Ekstrak fraksi $n$-Butanol (B) } \\
\hline $\mathrm{EAK}_{1} \mathrm{U}_{1}$ & $\mathrm{EAK}_{2} \mathrm{U}_{1}$ & $\mathrm{EAK}_{3} \mathrm{U}_{1}$ & $\mathrm{BK}_{1} \mathrm{U}_{1}$ & $\mathrm{BK}_{2} \mathrm{U}_{1}$ & $\mathrm{BK}_{3} \mathrm{U}_{1}$ \\
$\mathrm{EAK}_{1} \mathrm{U}_{2}$ & $\mathrm{EAK}_{2} \mathrm{U}_{2}$ & $\mathrm{EAK}_{3} \mathrm{U}_{2}$ & $\mathrm{BK}_{1} \mathrm{U}_{2}$ & $\mathrm{BK}_{2} \mathrm{U}_{2}$ & $\mathrm{BK}_{3} \mathrm{U}_{2}$ \\
$\mathrm{EAK}_{1} \mathrm{U}_{3}$ & $\mathrm{EAK}_{2} \mathrm{U}_{3}$ & $\mathrm{EAK}_{3} \mathrm{U}_{3}$ & $\mathrm{BK}_{1} \mathrm{U}_{3}$ & $\mathrm{BK}_{2} \mathrm{U}_{3}$ & $\mathrm{BK}_{3} \mathrm{U}_{3}$ \\
\hline
\end{tabular}

Keterangan: $E A K_{1} U_{1}=$ perlakuan konsentrasi 1 ekstrak fraksi etilasetat pada ulangan 1 dst...

Tabel 4. Hasil uji bioaktivitas larvasida biji kolowe (C. excelsus) terhadap larva Nyamuk Aedes Aegypti

\begin{tabular}{clc}
\hline No & Bahan & $\begin{array}{c}\text { Nilai Lethal Concentration (LC50) } \\
\text { dalam ppm }\end{array}$ \\
\hline 1 & Serbuk Biji segar & 230,60 \\
2 & Serbuk kering & 225,55 \\
3 & Ekstrak kasar (metanol) & 245,70 \\
4 & Ekstrak fraksi $n$-butanol & 235,75 \\
5 & Ekstrak fraksi etilasetat & 250,55 \\
\hline
\end{tabular}

Sumber: Rijai (2007)

Tabel 4 menunjukkan bahwa bioaktivtas setiap sediaan adalah relatif sama, meskipun sediaan biji kering menunjukkan bioaktivtas yang lebih baik tetapi perbedaannya dengan esktrak lain tidak signifikan. Namun demikian hasil pengujian tersebut menunjukkan bahwa biji kolowe sangat baik digunakan sebagai pemberantas jentik nyamuk penyebab BDB. Hal ini ditinjau dari segi kemudahan pembuatan sediaan serbuk kering dan juga efektivitas sebagai pembasmi telur dan larva nyamuk $A$. aegypti. Ekologi nyamuk A. aegypti di Indonesia sangat cocok sehingga telah menjadi salah satu penyebab kematian. Oleh karena itu diperlukan berbagai usaha untuk menghambat populasi nyamuk tersebut. Hasil penelitian merupakan sumbangan penting yang perlu diteliti lebih lanjut hingga pada pemanfaatan. 


\section{KESIMPULAN DAN SARAN}

Kesimpulan dari penelitian ini adalah bahwa biji kolowe (C. excelsus) memiliki bioaktivitas yang cukup kuat untuk membasmi jentik nyamuk penyebab deman berdarah (Aedes aegypti). Semua sediaan menunjukkan bioaktivitas yang cukup kuat sehingga dapat dipilih sediaan yang praktis dan mudah pembuatannya. Serbuk kering menunjukkan bioaktivitas lebih kuat dari ektrak kasar dan fraksi-fraksinya. Hal ini menggambarkan kemudahan sediaan untuk pemanfaatannya.

\section{SARAN-SARAN}

Biji segar buah kolowe mudah terjadi infasi jamur sehingga menunjukkan perubahan fisik yang signifikan secara visual. Hal ini juga terjadi pada serbuk kering meskipun tidak sama dengan biji segar. Keadaan ini diperlukan penelitian stabilitas, baik itu stabilitas aktivitas maupun fisik terhadap serbuk kering yang telah dinyatakan potensial tersebut.

\section{DAFTAR PUSTAKA}

1. Harriman, N. 1997, Plants Number Index. Biology Department, Univeristy of Wisconsin; Oskhosh.

2. Hostettman, K.; \& Marston, A. 1995, Saponins: A Chemistry and Pharmacology of Natural Products. Cambridge University Press, First Published; New York.

3. Rijai, L. 2004, Kajian Kimiawi dan Bioaktivitas Tumbuhan Kolowe (Chydenanthus excelsus). Disertasi, UNPAD; Bandung

4. Colegate, S. M.; \& Molyneux, R.J. 1993, In Bioactive Natural Products: Detection, isolation, and structural determination, (3rd edition), 349-399, CRC Press; Boca Raton; London; Tokyo.

5. Rijai, L. 2007, Kajian Bioaktif Potensial Biji Kolowe (Chydenanthus excelsus) untuk Pemanfaatan, LPPM, UNMUL; Samarinda 